\title{
QUALITY AND SAFETY ATTRIBUTES OF ACCLIMATED SPECIES FAGOPYRUM ESCULENTUM MOENCH
}

\author{
SAMI KHALASS ${ }^{1}$, CARMEN POPESCU $^{2,3 *}$, DUMITRU LUPULIASA $^{1}$ \\ 1 "Carol Davila" University of Medicine and Pharmacy, Bucharest, Faculty of Pharmacy \\ ${ }^{2}$ S.C. HOFIGAL Export Import S.A., Bucharest, Romania \\ 3 "Vasile Goldiş" Western University, Arad, Faculty of Pharmacy \\ *corresponding author: popescu_carmen88@yahoo.com
}

\begin{abstract}
The aim of this study was the characterization of the buckwheat seeds (Fagopyrum esculentum Moench.) powder derived from a Ukrainian species acclimated in Southern Romania, in terms of physicochemical and microbiological characterization and also the nutritional attributes, in order to develop finished products as dietary supplements with this naturally active ingredient. The results obtained from the physicochemical and microbiological analysis of the samples of Fagopyrum esculentum Moench. demonstrated that they are within the limits of admissibility stipulated by the $9^{\text {th }}$ European Pharmacopoeia and the literature. To highlight the attributes of the nutritional profile and quality in the view of ensuring a high level of consumer health protection, the energy value of Buckwheat seeds powder - Fagopyrum esculentum Moench. was determined in accordance with EU Regulation 1169/2011.
\end{abstract}

\section{Rezumat}

Obiectivul acestui studiu a fost caracterizarea pulberii din semințe de hrișcă (Fagopyrum esculentum Moench.) obținută din materialul al plantei aclimatizate în sudul României, rezultată din semințe provenind din Ucraina. Studiul a inclus determinări fizico-chimice și microbiologice precum și atributele nutriționale cu intenția de a dezvolta suplimente alimentare conținând acest produs vegetal. Rezultatele obținute în urma analizelor fizico- chimice și microbiologice a pulberii din seminţe de Fagopyrum esculentum Moench. au demonstrat faptul că acestea se încadrează în limitele de admisibilitate prevăzute de Farmacopeea Europeană ediţia a 9-a și literatura de specialitate. Pentru a evidenția atributele valorii și calității nutriționale în vederea asigurării unui nivel ridicat de protecție a sănătății consumatorilor, valoarea energetică a pulberii din semințe de hrișcă - Fagopyrum esculentum Moench. a fost stabilită în conformitate cu reglementarea UE 1169/ 2011.

Keywords: Fagopyrum esculentum, buckwheat, physicochemical characterisation, microbial contamination, dietary supplements

\section{Introduction}

Buckwheat (Fagopyrum esculentum Moench., Polygonaceae) is grown throughout a large area of Asia and Southeast Asia as a crop and is very popular in Slovenia, Poland, Ukraine, the Republic of Moldova and Russia [17]. Common buckwheat (Fagopyrum esculentum Moench.) is a crop of secondary importance in many countries. The pant is not a cereal, but the seeds are usually classified among the cereal grains because of their similar usage. The proteins of buckwheat are rich in the essential amino acid lysine, unlike common cereals. Common buckwheat contains high nutritive substances (63\% carbohydrate, $11.7 \%$ protein, $2.4 \%$ fat, $9.9 \%$ fibre, $11 \%$ water and $2 \%$ minerals), being a gluten free, nectariferous and pharmaceutical plant, with a high content of flavonoids, namely rutin and quercetin $[7,15,17]$. Health benefits attributed to buckwheat include plasma cholesterol level reduction, neuroprotection, anticancer, antiinflammatory, hypoglycaemic effects, and improvement of hyper-tensive conditions. In addition, buckwheat has been reported to possess prebiotic and antioxidant activities. In vitro and animal studies suggest that buckwheat's bioactive compounds, such as D-chiro-inositol, the proteins and flavonoids may be partially responsible for the observed effects $[4,5,12,18]$.

Rutin [16], quercetin and other polyphenols are well known as strong anticancer agents against colon cancer [8] and the phenolic compounds are cited as lowering blood glucose and lipids. Buckwheat has a very low content of prolamine and, based on chemical and immunological studies, can be a valuable source of dietary proteins for glutensensitive individuals [6].

\section{Materials and Methods}

Physicochemical characterization of the buckwheat seed powder. Three samples of buckwheat seed powder S1, S2, S3, samples from indigenous culture in Southern Romania, harvested during the same period, from different plot lots were used. The 
FARMACIA, 2018, Vol. 66, 4

physicochemical tests were performed according to the European Pharmacopoeia $9^{\text {th }}$ Ed. and the Romanian Pharmacopoeia $10^{\text {th }}$ Ed. [10, 19]. The parameters evaluated were: macroscopic characters; loss on drying, \%; total ashes $\%$ [2]; content in total polyphenols expressed as chlorogenic acid $\%[8,20]$; content in total flavonoids expressed as rutin $\%$ [3]; content in total protein $\%$ [5]; content in fatty oil \% [14] and mineral content $[\mathrm{ppm}] / 100 \mathrm{~g}$ of product $[17,18]$. Reagents. The following reagents were used: sodium phosphowolframate solution, caffeic acid, ethanol, methanol, rutin (reference standard) $0.01 \%$ solution in methanol, selenium, glucose, hydrochloric acid and nitric acid. All reagents were purchased from Sigma Aldrich and were of analytical purity.

Equipment. a Jasco V-650 UV-Vis spectrophotometer was used to determine the total polyphenol content expressed as chlorogenic acid and the total flavonoid expressed as rutin; distillation and mineralization installation for total protein content; Soxhlet extraction apparatus for fatty oil content; a Shimadzu AA-6300 atomic absorption spectrophotometer equipped with cathode ray lamps as a source of radiation, deuterium lamp used as a background corrector, acetylene-air flame/nitrous-acetylene nitrous flame for determining the content of minerals, trace elements and heavy metals.

The microbiological characterization of the three samples of the buckwheat seeds powder product from the point of view of microbial contamination was carried out in accordance with the regulations of the European Pharmacopoeia $9^{\text {th }}$ Ed. $[1,10,20]$. Reagents used, culture mediums and solutions for determining the total number of aerobic microorganisms (TAMCs) were: casein soya bean digest agar, buffered sodium chloride broth $\mathrm{pH}=7.0$; for the determination of the total number of yeasts and filamentous fungi (TYMC): Sabouraud agar with dextrose, buffered sodium chloride broth $\mathrm{pH}=7.0$; for the isolation and identification of gram-negative bacteria-tolerant bile salts: Enterobacteria enrichment broth (Mossel), violet red bile glucose agar, casein soya bean digest broth. For the control of specific microorganisms, namely Escherichia coli and Salmonella sp. there were used: MacConkey broth, MacConkey agar, casein soya bean digest broth, triple sugar iron agar (TSI), Rappaport Vassiliadis Salmonella enrichment broth, xylose, lysine, deoxycholate agar.

Equipment. Venticell 111 owen, Incucell Incubator 404, Friocell Incubator 404, microbiological boxlaminar air flow Telstar AV 100 and BSC-EN I-IV. The energy value of the unique common sample was determined according to Food Energy- methods of analysis and conversion factors/ FAO Food and Nutrition [2, 11, 13], and the EU Regulation 1169/ 2011 [9]. The energy value was calculated for each of the categories of proteins, carbohydrates, lipids, by multiplying the quantity obtained with the conversion factor expressed in KJ and Kcal. The buckwheat seeds powder sample has been tested by the National Institute for Research and Development for Food Bioresources - IBA Bucharest, Romania.

\section{Results and Discussion}

The results of the physicochemical analysis of the buckwheat seed powder (Fagopyrum esculentum Moench.) demonstrate a conjugate behaviour of the three analysed samples, and the results are within the limits of admissibility imposed by the Eur. Ph. $9^{\text {th }}$ Ed. (Table I).

Table I

The results of the physico-chemical analysis of the product of buckwheat seed powder (Fagopyrum esculentum

\begin{tabular}{|c|c|c|c|c|c|}
\hline $\begin{array}{c}\text { Crt. } \\
\text { No. }\end{array}$ & Characteristics & $\begin{array}{c}\text { Limits of } \\
\text { admissibility }\end{array}$ & $\begin{array}{c}\text { Results for } \\
\text { sample S1 }\end{array}$ & $\begin{array}{c}\text { Results for } \\
\text { sample S2 }\end{array}$ & $\begin{array}{c}\text { Results for } \\
\text { sample S3 }\end{array}$ \\
\hline 1 & Macroscopic characters & $\begin{array}{c}\text { The product is an } \\
\text { achene with three } \\
\text { edges, with a gray } \\
\text { or blackish coating }\end{array}$ & met & met & met \\
\hline 2 & Drying loss, \%, max. & 15.0 & 8.68 & 8.71 & 8.66 \\
\hline 3 & Total ash, \%, max. & 5.00 & 3.23 & 3.22 & 3.25 \\
\hline 4 & $\begin{array}{c}\text { Content in total polyphenols expressed } \\
\text { as chlorogenic acid, \%, min. }\end{array}$ & 0.40 & 0.50 & 0.52 & 0.50 \\
\hline 5 & $\begin{array}{c}\text { Content in total flavonoids expressed } \\
\text { in rutin, \%, min. }\end{array}$ & 0.10 & 0.12 & 0.13 & 0.12 \\
\hline 6 & Content in total protein, \%, min. & 8.00 & 8.63 & 8.66 & 8.64 \\
\hline 7 & Content in fatty oil, \%, min. & 1.00 & 1.36 & 1.40 & 1.38 \\
\hline
\end{tabular}

In addition, there is a very good content in mineral salts of calcium, magnesium, sodium and potassium and of trace elements: manganese, iron, zinc. Also, the samples did not show heavy metals, lead and cadmium (Table II). 
Table II

The mineral content of buckwheat seed powder (Fagopyrum esculentum Moench.)

\begin{tabular}{|c|c|c|c|c|c|c|c|c|c|c|c|}
\hline \multirow{2}{*}{$\begin{array}{l}\text { Sample: powder from buckwheat seeds } \\
\text { (Fagopyrum esculentum Moench.) }\end{array}$} & \multicolumn{11}{|c|}{ Mineral content $[\mathrm{ppm}] / \mathbf{1 0 0 g}$} \\
\hline & $\mathbf{C a}$ & Mg & $\mathbf{N a}$ & $\mathbf{K}$ & Mn & $\mathbf{F e}$ & $\mathbf{Z n}$ & $\mathbf{C u}$ & $\mathbf{C r}$ & $\mathbf{P b}$ & Cd \\
\hline S1 & 125 & 365 & 1800 & 3300 & 12 & 16 & 16 & ND & ND & ND & ND \\
\hline $\mathrm{S} 2$ & 128 & 360 & 1810 & 3310 & 10 & 15 & 14 & ND & ND & ND & ND \\
\hline S3 & 127 & 362 & 1815 & 3308 & 13 & 16 & 14 & ND & ND & ND & ND \\
\hline
\end{tabular}

ND - not detectable

The results obtained on the powder samples of contamination are presented in Table III. buckwheat seed from the point of view of the microbial

Table III

The results obtained on the powder samples from buckwheat seeds from the point of view of microbial contamination

\begin{tabular}{|c|c|c|c|c|}
\hline Characteristics & $\begin{array}{c}\text { Limits of } \\
\text { admissibility }\end{array}$ & $\begin{array}{l}\text { Results for } \\
\text { sample S1 }\end{array}$ & $\begin{array}{l}\text { Results for } \\
\text { sample S2 }\end{array}$ & $\begin{array}{c}\text { Results for } \\
\text { sample S3 }\end{array}$ \\
\hline $\begin{array}{c}\text { Microbial contamination: } \\
\text { Total aerobic microorganisms (TAMC), } \\
\text { CFU/g, max. } \\
\text { Total combined yeast and filamentous } \\
\text { fungi (TYMC), CFU/g, max. } \\
\text { Gram-negative bacteria-tolerant bile salts, } \\
\text { CFU/g, max. } \\
\text {-Escherichia coli } / \mathrm{g} \\
\text {-Salmonella sp. } / 25 \mathrm{~g}\end{array}$ & $\begin{array}{l}1 \times 10^{5} \\
1 \times 10^{4} \\
1 \times 10^{4} \\
\text { absent } \\
\text { absent }\end{array}$ & $\begin{array}{c}2.6 \times 10^{2} \\
1.3 \times 10 \\
<10 \\
\text { absent } \\
\text { absent }\end{array}$ & $\begin{array}{c}2.0 \times 10^{2} \\
1.0 \times 10 \\
<10 \\
\text { absent } \\
\text { absent }\end{array}$ & $\begin{array}{c}2.3 \times 10^{2} \\
1.1 \times 10 \\
<10 \\
\text { absent } \\
\text { absent }\end{array}$ \\
\hline
\end{tabular}

The results obtained in the analysis of the microbial contamination of the seed powder of Fagopyrum esculentum Moench. taken into consideration demonstrated that they are of high quality, subject to the admissibility limits stipulated by the European Pharmacopoeia $9^{\text {th }}$ Ed. It is noteworthy that the unprocessed natural product had microbial contamination values related to the total number of aerobic microorganisms (TAMC), the combined

total number of yeasts and filamentous fungi (TYMC) and gram-negative bacteria tolerant to bile salts lower with a logarithmic rate of $10^{3}$ against the admissibility limits imposed, as well as the absence of gram negative pathogenic microorganisms Escherichia coli and Salmonella spp.

Determination of the energy value. The nutritional profile of the analysed powder is presented in Table IV and compared with data from literature.

Table IV

Determination of energy value of buckwheat seed powder

\begin{tabular}{|c|c|c|c|c|}
\hline Features & $\begin{array}{l}\text { U.M - Units of } \\
\text { Measurement }\end{array}$ & $\begin{array}{c}\text { Methods of } \\
\text { Analysis }\end{array}$ & $\begin{array}{c}\text { Results acclimated } \\
\text { species }\end{array}$ & $\begin{array}{l}\text { Data from } \\
\text { literature }\end{array}$ \\
\hline Energy value & Kcal/100g & UE Regulations 1169/2011 & 364 & 343 \\
\hline Energy value & $\mathrm{KJ} / 100 \mathrm{~g}$ & UE Regulations 1169/2011 & 1543 & 1435 \\
\hline Protein & $\%$ & The Kejdhal method & 11.92 & 11.7 \\
\hline Lipids & $\%$ & Soxhlet extraction & 3.51 & 2.4 \\
\hline Glucides of which: & $\%$ & Reg. UE 1169/2011 & 71.19 & 63 \\
\hline sugars & $\%$ & Modified Mohr method & $<0.08$ & 1.1 \\
\hline Moisture & $\%$ & FR $10^{\text {th }} \mathrm{Ed}$. & 11.7 & 11 \\
\hline Ash & $\%$ & FR $10^{\text {th }} \mathrm{Ed}$. & 1.68 & 1.61 \\
\hline
\end{tabular}

\section{Conclusions}

Our research results demonstrated that acclimated Fagopyrum esculentum Moench. conforms with the international standards in terms of: microbial contamination, total protein content, energy value, lipids and carbohydrates. The results were comparable to those in the literature regarding the parameters: humidity, ash, content in total polyphenols, expressed as chlorogenic acid, content in total flavonoids, expressed as rutin.

Buckwheat seed powder obtained from the acclimated plant can be used as a quality and safe active ingredient for the development of dietary supplements.

\section{Acknowledgements}

This paper was published with the financial support of FDI grant CNFISFDI-2018-0507, funded by National 
FARMACIA, 2018, Vol. 66, 4

Council for Higher Education, Ministry of National Education (Romania).

\section{References}

1. Ancuceanu R, Dinu M, Hovaneţ M, Anghel A, Popescu C, Negreş S, A survey of plant iron content - A semi-systematic review. Nutrients, 2015; 7(12): 1032010351.

2. Association of $\mathrm{O}$ cial Analytical Chemists, $\mathrm{O}$ cial methods of analysis, $15^{\text {th }}$ Ed. Washington, DC, 1990.

3. Bao T, Wang Y, Li YT, Gowd V, Niu XH, Yang HY, Chen LS, Chen W, Sun CD, Antioxidant and antidiabetic properties of tartary buckwheat rice flavonoids after in vitro digestion. $J$ Zhejiang Univ Sci B., 2016; 17(12): 941-951.

4. Pîrvu L, Sha'at F, Miclea LC, Savopol T, Neagu G, Udeanu DI, Moisescu MG, Polygonum bistorta L. herba et flores. Polyphenols profile, antioxidant properties and cytotoxic effect on murine fibroblast cell line NIH3T3. Farmacia, 2017; 65(4): 571-576.

5. Bhavsar GJ, Sawate AR, Kshirsagar RB, Chappalwar VM, Studies on physico-chemical characteristics of buckwheat and its exploration in bread as functional food. Int J Eng Res Technol., 2013; 12(1): 3971-3980.

6. Kim CD, Lee WK, No KO, Park SK, Lee MH, Lim SR, Roh SS, Anti-allergic action of buckwheat (Fagopyrum esculentum Moench) grain extract. Int Immunopharmacol., 2003; 3(1): 129-136.

7. Lee CC, Shen SR, Lai YJ, Wu SC. Rutin and quercetin, bioactive compounds from tartary buckwheat, prevent liver inflammatory injury. Food Funct., 2013; 4(5): 794-802.

8. Dinu M, Olaru OT, Dune A, Popescu C, Nitulescu GM, Ancuceanu RV, The obtaining and characterization of a rich-phenolic extract from Amaranthus hypochondriacus L.. Rev Chim (Bucharest), 2016; 67(5): 880-883.

9. EU Regulation 1169/ 2011 of the European Parliament and of the Council of 25 October 2011.

10. European Pharmacopoeia, 9.0 edition, (2016), Council of Europe, Strasbourg, France.
11. Food Energy methods of analysis and conversion factors/FAO Food and Nutrition, Technical workshop on food energy: methods of analysis and conversion factors, 2003, paper 77, 7- 37, ISSN 0254-4725.

12. Giménez-Bastida HA, Zieliński H, Buckwheat as a functional food and its effects on health. J Agric Food Chem., 2015; 63(36): 7896-7913

13. Ahrendt DM, Ergogenic aids: counseling the athlete. Am Fam Physician, 2001; 63: 913-922.

14. Velescu BS, Anuţa V, Nițulescu GM, Olaru OT, Orțan A, Ionescu D, Ghica MV, Drăgoi CM, Dinu Pîrvu CE, Pharmaceutical assessment of Romanian crops of Anthriscus sylvestris (Apiaceae). Farmacia, 2017; 65(6): 824-831.

15. Kokalj Ladan M, Straus J, Tavčar Benković E, Kreft S, FT-IR-based method for rutin, quercetin and quercitrin quantification in different buckwheat (Fagopyrum) species. Sci Rep., 2017; 7(1): 1-8.

16. Nassiri-Asl M, Shariati-Rad S, Zamansoltani F. Anticonvulsive effects of intracerebroventricular administration of rutin in rats. Progress in neuropsychopharmacology \& biological psychiatry. 2008; 32: 989-993.

17. Ratan P, Kothiyal P, Fagopyrum esculentum Moench (common buckwheat) edible plant of Himalayas: A Review. Asian Journal of Pharmacy and Life Science, 2011; 1(4): 1-17.

18. Sindhu R, Khatkar BS, Composition and functional properties of common buckwheat (Fagopyrum esculentum moench) flour and starch. IJIRAS, 2016; 3(7): 154-159.

19. Romanian Pharmacopoeia $-X^{\text {th }}$ Edition, National Medicines Agency, Medical Publishing House, 2008, Bucharest, Romania.

20. Žvikas V, Pukelevičienè V, Ivanauskas L, Romanovskaja D, Jakštas V, Evaluation of phenolic antioxidant content in organically and conventionally grown buckwheat herb crop and its regrowth. J Sci Food Agric., 2017; 97(10): 3278-3283. 